\title{
Are The Right Students Receiving Need Based Federal Student Financial Aid
}

\author{
Joseph Kennedy, Edward Waters College, USA
}

\begin{abstract}
Students at a college or university who receive need-based financial aid, receive a tremendous financial resource compared to those students who do not receive need based financial aid. A sample of 100 students from various backgrounds and skills were surveyed. The survey asked questions of the two student groups: received need based financial aid group and non-need based financial aid group. The overall questions were intended to identify specific traits and measures of the student's performance.
\end{abstract}

Keywords: Federal Student Financial Aid, Education, Learning, Ethics

\section{INTRODUCTION}

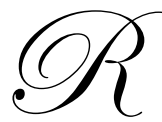

Tesearch was conducted on students who work in the financial aid office at a local university, the research inferences draws a hypothesis, that students who receive need based financial aid do not perform academically as well as students who do not receive need based financial aid. Students who receive need based financial aid come from poverty level family incomes. The student families report economically on the student aid report that they receive subsistence from government or local agencies. Many of the parents of this student group have not obtained a college degree, and one-fourth of the parents who receive subsistence have not obtained their high school diplomas. The majority of the students in this classification come from single parent families. The university must select special admit students to the university. These students are selected based on their socio-economic stature. These students are given an opportunity to receive a degree from an institution that they would not normally be accepted or succeed from. Students, who do not receive need based financial aid, are more likely to come from middle to upper class families. A college or university contributes seventy to eighty percent of scholarships to students who receive high school grade point averages of 3.0 or higher. With this trend, most students who receive scholarships have a surplus of income from their families because, the families have already allocated funds for their children to attend college, resulting in the student receiving financial aid due to their academics causing an excess in funds. Student's, who receive scholarships based on their academic credentials, are not considered recipients of Federal Aid, resulting purely in the scholarship money coming from a particular state or private organization.

\section{LITERATURE REVIEW}

The United States Government, Department of Education, Federal Methodology of Need Based Financial Aid states; that when a student who is dependant upon their parents whose annual income is below or at twelve thousand to fifteen thousand dollars per year, that student shall receive need based financial aid. When students and their parents complete a Free Application for Federal Student Aid (FAFSA), information from this report identifies students and their families of federal and state aid and the parents' educational achievements. Baldauf, S. (1997). Merit Scholarships: Pivotal shift in aid more states - and now the U.S. - are giving students financial aid on the basis of grades, after decades on focusing on need. Christian Science Monitor, 1,2 states, "If you have asked me ten years ago, I would have said that need-based aid was the big trend, says David Breneman, Dean of the Education School at the University of Virginia in Charlottesville and a supporter of need-based aid. But now, need has lost a bit of its panache." The civil rights era of the mid-1960s and early 1970s was a heyday for need-based college aid, and federal programs grew exponentially. Last year, state and federal governments and private institutions gave out a total of fifty billion in college aid - nearly thirty five billion of it earmarked for poor students." Students who are 
eligible for need based financial aid, receive Pell Grants as undergraduate students. At colleges and university's today, Pell Grants are dispersed according to the Federal Methodology and students receive these funds after the first two weeks of school. According to James P. McGovern (1997). Boost Pell Grants to Five Thousand Dollars. Christian Science Monitor, 20:3 he states "that educators understand that students are struggling to meet rising college costs. The average tuition at a four-year public college in Massachusetts is more than four thousand dollars; the average private school costs nearly four times that amount. In 1980 through 1981, the average Pell Grant award paid for $26 \%$ of the total annual costs of attending a four-year public institution. Today, the average award covers only sixteen percent of the cost. The Pell Grant program is the heart of Federal Grant Aid for families in need. It targets those students most likely not too attend college because of a lack of funds. These are the children of modest-income, working families, and those of middle-income families who are struggling to send several children to college at the same time." However, students receive this type of financial aid based on entitlement, if you qualify, you can receive it at any title IV college or university. Many students who are classified as need based students, must acquire other types of financial assistance, such as, loans and work. This trend is very disheartening, when you see students who have enormous debt loads when they graduate from college. According to Pulliam, L. (1998, Fall). Your money; money talks; so you want to fool the financial aid folks - why not just rob the needy? Los Angeles Times, 3. She states that "thousands of genuinely needy students graduate each year with crushing student loan debts because of a lack of available financial aid; any paper-shuffling your friend might due to hide the ward's lack of neediness would essentially be stealing money from them. That is legally and morally wrong - and a lousy example to set for the student." In the last ten years, a disturbing trend in college recruitment has been taking place. Colleges and universities are recruiting top students and using need based financial aid to support the students. Typical student's who do not receive need based financial aid money at a college or university is in middle to upper class income bracket. These students and their families receive $70 \%$ to $80 \%$ of the college costs based on their academic achievements in high school. High academic achievements for students coming into a college or university have been promoted by new state legislation called "Bright Future Scholarships." Students who do not receive need based financial aid, but do not receive the scholarships are still in middle to upper class incomes, reported by their student aid report. Students who receive scholarships, supplemented by need based funds are recruited, due to their high academic standing, even though they do not need this financial assistance. This is a very disturbing trend, Many people believe that need based financial aid should be based on academic performance but, socio-economic status and an environmental factors must play a role to determine who should receive need based financial aid. According to Bronner, E. (1998). Colleges use financial aid to attract college students. The New York Times, $3^{\text {rd }}$ Edition, A-7. He states that "the best colleges have taken a more subjective approach to need, adjusting scholarships to match or exceed offers that students get elsewhere. At the same time, other colleges are taken need into account where they previously had not, rejecting some poor borderline applicants in favor of better-off ones. And more colleges are dangling scholarships to top students whether or not their families need the money. If you go back twenty years, most folks thought of the student aid budget (need-based financial aid) as a charity operation run on the side, McPherson said, now it is a real strategic component of revenue raising and enrollment management. There are different prices for different customers, like how airlines price their seats." Need based financial aid was determined by the Federal Methodology as a way of making all colleges and universities accessible to all students. Globalization of the market place and great demand for top quality personnel, have caused colleges and universities to recruit the best and award financial aid to non need based students to have them come to their institutions. In some states, affirmative action programs have ceased. This trend has caused colleges and universities to redistribute need based financial aid according to need, but what type of need; the universities need or the need based students? According to Haworth, K. (1998, Winter). The University of Minnesota may alter program used to recruit minority students. The Chronicle, 44, issue 22, A-33. She states that "public colleges in such states as California and Texas have been forced to end their affirmative-action programs because of legal or political changes." According to the Department of Education's results of the Free Application for Federal Student Aid, the majority of students receiving need based financial aid are minority students. According to Bronner, E. (1998, Summer). Financial aid to needy college applicants wanes more being spent on scholarships to attract top students. The New York TimesDenver Post, A-03. He states that "will institutions meet the needs of lower income students? Shapiro asked. These days, almost the entire enrollment rate increase is from the middle income and above. The gap between whites and non-whites going to college is greater than it was in nineteen eighty. The poor are increasingly restricted to community colleges, even being squeezed out of four-year public institutions." 


\section{METHODOLOGY}

One hundred students were chosen and were asked to complete a survey. The students were chosen from a group of student employees at a local university financial aid office. Five students were asked to distribute 20 surveys to their fellow classmates. Of the students' surveyed, 60 were on need based financial aid and 40 were not. The results of 2 students on financial aid and 2 students who were not on financial aid were dropped because of incomplete responses.

The general implications and conclusions should be true, but the following apply:

1. Because the sample was not truly a simple random sample, rather one of convenience (due to time and money considerations) there is expected to be bias in the results analysis' section.

2. Since the sample was only taken at a local university, the following conclusion can only apply to the students at that university.

- $\quad$ Two sample independent t-procedures were used to analyze the data.

\section{RESULTS}

A total of five individual hypothesis tests were performed at the 0.05 level of significance (Alpha). Each test was conducted to determine if students on financial aid differ in some respect to those that are not on financial aid. An analysis was conducted to determine the effects of five independent variables on the dependent variable GPA. The variables are defined as:

The first hypothesis test was conducted to determine if the number of hours of television that a need based financial aid student (1) watches per night, differentiates from students who were not on need based financial aid (0). Students who are not on need based financial aid (0) watched on the average of 11.79 hours per week with a standard deviation of 9.00 hours per week. Students who were on need based financial aid (1) watched an average of 10.21 hours of television per week with a standard deviation of 8.42 hours per week. The null (Ho) and alternative (H1) hypotheses are defined as:

- Ho: There is not a significant difference between the mean number of hours of television watched between students on need based financial aid and those who are not.

- H1: There is a significant difference between the mean number of hours of television watched between students on need based financial aid and those who are not.

The t-test statistic value turned out to be 0.86 , resulting in a p-value of 0.39 . Since the p-value is not less that our alpha level, the null hypothesis can not be rejected. This indicates that there is insufficient evidence to indicate that there is significant difference between the mean number of hours of television watched between students on need based financial aid and those who are not. A 95\% confidence interval indicates that the true mean difference in the average number of television watched per week lies in the interval of ( -2.1 hours per week and 5.2 hours per week).

The second hypothesis test was conducted to determine the number of work hours that a need based financial aid student (1) works during a typical week, differentiates from students who were not on need based financial aid (0). Students who are not on need based financial aid (0) worked on the average of 12.0 hours per week with a standard deviation of 12.7 hours per week. Students who were on need based financial aid (1) worked on the average of 10.6 hours per week with a standard deviation of 10.9 hours per week. The null (Ho) and alternative (H1) hypotheses are defined as:

- $\quad$ Ho: There is not a significant difference between the mean number of hours worked per week between students on need based financial aid and those who are not.

- $\quad$ H1: There is a significant difference between the mean number of hours worked per week between students on need based financial aid and those who are not. 
The t-test statistic value turned out to be 0.56 , resulting in a p-value of 0.58 . Since the p-value is not less that our alpha level, the null hypothesis can not be rejected. This indicates that there is insufficient evidence to indicate that there is significant difference between the mean number of hours worked between students on need based financial aid and those who are not. A 95\% confidence interval indicates that the true mean difference in the average number of hours worked per week lies in the interval of (-3.6 hours per week and 6.4 hours per week).

The third hypothesis test was conducted to determine if the number of study hours that a need based financial aid student (1) studied per week, differentiates from students who were not on need based financial aid (0). Students who are not on need based financial aid (0) studied on the average of 11.88 hours per week with a standard deviation of 7.14 hours per week. Students who were on need based financial aid (1) studied an average of 13.97 hours per week with a standard deviation of 9.29 hours per week. The null (Ho) and alternative (H1) hypotheses are defined as:

- Ho: There is not a significant difference between the mean number of hours studied between students on need based financial aid and those who are not.

- $\quad$ H1: There is a significant difference between the mean number of hours studied between students on need based financial aid and those who are not.

The t-test statistic value turned out to be -1.17 , resulting in a p-value of 0.24 . Since the p-value is not less that our alpha level, the null hypothesis can not be rejected. This indicates that there is insufficient evidence to indicate that there is significant difference between the mean number of student study hours per week between students on need based financial aid and those who are not. A 95\% confidence interval indicates that the true mean difference in average number of television watched per week lies in the interval of (-5.6 hours per week and 1.4 hours per week).

The fourth hypothesis test was conducted to determine the grade point average that a need based financial aid student (1) has, compared to students who were not on need based financial aid (0). Students who are not on need based financial aid (0) has a grade point average of 3.25 with a standard deviation of 0.59 . Students who were on need based financial aid (1) has a grade point average of 3.10 with a standard deviation of 0.49. The null (Ho) and alternative (H1) hypotheses are defined as:

- Ho: There is not a significant difference between the mean number of grade points on need based financial aid students and those who are not.

- H1: There is a significant difference between the mean number of grade points on need based financial aid students and those who are not.

The t-test statistic value turned out to be 1.34 , resulting in a p-value of 0.18 . Since the p-value is not less that our alpha level, the null hypothesis can not be rejected. This indicates that there is insufficient evidence to indicate that there is significant difference between the mean number of grade point average between students on need based financial aid and those who are not. A 95\% confidence interval indicates that the true mean difference in average number of grade points lie in the interval of (-0.072 GPA and 0.370 GPA).

The fifth hypothesis test was conducted to determine if the number of hours a need based financial aid student (1) goes out per week, differentiates from students who were not on need based financial aid (0). Students who are not on need based financial aid ( 0 ) went out an average of 2.32 hours per week with a standard deviation of 1.34 hours per week. Students who were on need based financial aid (1) went out on an average of 2.24 hours per week with a standard deviation of 1.30 hours per week. The null (Ho) and alternative (H1) hypotheses are defined as:

- Ho: There is not a significant difference between the mean number of social hours between students on need based financial aid and those who are not.

- $\quad$ H1: There is a significant difference between the mean number of social hours between students on need based financial aid and those who are not. 
The t-test statistic value turned out to be 0.27 , resulting in a p-value of 0.79 . Since the p-value is not less that our alpha level, the null hypothesis can not be rejected. This indicates that there is insufficient evidence to indicate that there is significant difference between the mean number of social hours between students on need based financial aid and those who are not. A 95\% confidence interval indicates that the true mean difference in the average number of social hours per week lies in the interval of ( -0.47 hours per week and 0.62 hours per week). The following statistical data and graphs are located in Appendix C and D.

\section{DISCUSSION}

In all five hypotheses the null hypothesis was not rejected. Based on the five survey questions, insufficient evidence was indicated that there was any significant differences between the students who receive need based financial aid and students who do not. In further review, the survey needs to accommodate more specific information, such as:

- $\quad$ Determine if the student receives scholarships; if so, what types', academic, athletic, or social club.

- Determine if the student is an independent or dependent student. If the student is dependent, approximate the family income. If the student is independent, determine his or her gross income per year.

- Determine if the student is in-state or out-of-state student. If the student's residency status is out-of-state, does he or she pay in-state tuition or out of state tuition?

- $\quad$ Determine gender; male or female.

- Determine age of the student.

- $\quad$ Determine nationality of the student.

After reviewing all of the surveys, the results of the information reflect that there is no disparity between need based financial aid students and non-need based financial aid students. However, further investigation must identify more relevant student information. Also, colleges and universities should be required to use need based financial aid as it was intended and not to be used as a tool to recruit affluent students who do not require, need based financial aid, according to Glenn (2007) Colleges should trim some of their financial-aid offers might sound vaguely heartless -- and might seem reminiscent of "enrollment management" strategies that have been heavily criticized for apparently allowing colleges to chase prestige at the expense of low-income students. According to the articles study, two colleges were analyzed and found that these colleges could allocate their financial-aid more efficiently; they could free up resources, to include offering more need-based financial aid, diversify the college's student bodies, or hire more faculty members. One of the colleges has a large endowment and a total enrollment of roughly 1,000 students. The other college has a small endowment, relatively low tuition, and a total enrollment of roughly 5,500 students. The study of the two colleges provides enrollment managers' with an oversimplified financial aid formula, it does not take into account that admissions officials have pre-conceived opinions about how likely a student is to enroll before calculating a student's financial-aid offer. Colleges calculate an applicant's "enrollment propensity" by looking at the past behavior of applicants with similar profiles. Admissions officers also make judgments of an applicant's leanings based on interviews and correspondence. Financial-aid offers ignore the fact that all the colleges may decide to offer that same scholarship. The yield rate money is perhaps going to students who are already likely to attend. (Yield rate refers to the percentage of students accepted at a college who choose to attend.)

\section{REFERENCES}

1. Glenn, D. (2007) Student aid offers may be too generous Chronicle of Higher Education 53, A.47

2. Baldauf, S. (1997). Merit Scholarships: Pivotal shift in aid more states - and now the U.S. - are giving students financial aid on the basis of grades, after decades on focusing on need. Christian Science Monitor, $1: 2$.

3. McGovern, J. (1997). Boost Pell grants to five thousand dollars. Christian Science Monitor, 20:3.

4. Pulliam, L. (1998, Fall). Your money; money talk; so you want to fool the financial aid folks-why not just rob the needy? Los Angeles Times, 3.

5. Bronner, E. (1998, Summer). Colleges use financial aid to attract top students. New York Times, $3^{\text {rd }}$ Edition, A-7. 
6. Haworth, K. (1998). University of Minnesota may alter program used to recruit minority students. The Chronicle of Higher Education, 44, A-33.

7. Bronner, E. (1998, Summer). Financial aid to needy college applicants wanes more being spent on scholarships to attract top students. New York Times-Denver Post, Final Edition, A-03.

\section{$\underline{\text { NOTES }}$}

